\title{
Effect of alcoholic extract of Apium graveolens leaves on some physiological properties of a broilers
}

\author{
S. A. Al - Gnami
}

Coll. of Vet. Med.-Univ. of Al - Qadisiya

e-mail: saadeyaali@yahoo.com

\begin{abstract}
This study was carried out on fourteen broiler arranged between $(1100-1500) \mathrm{gm}$. in weight to estimate the effect of drenching of alcoholic extract of Apium graveolens leaves on some physiological properties. The birds were divided into two groups which are control and treatment group seven birds for each group. The birds in both groups are housed in same condition, include temperature, light, food, and water during experiment period.The control group cavaged with $1 \mathrm{ml}$ distilled water while treatment group cavaged with $10 \mathrm{mg} \backslash \mathrm{kg}$. B.W. of alcoholic extract of Apium graveolens leaves dissolved in $1 \mathrm{ml}$ of distilled water for two weeks. The birds were weighted and blood sample were taken two times before and after treatment. The results of this study was revealed a significant increase in red blood cells count, hemoglobin concentration, and packed cell volume, while there is no significant changes in white blood cells count, and body weight .
\end{abstract}

key words: Apium graveolens, physiological properties, birds

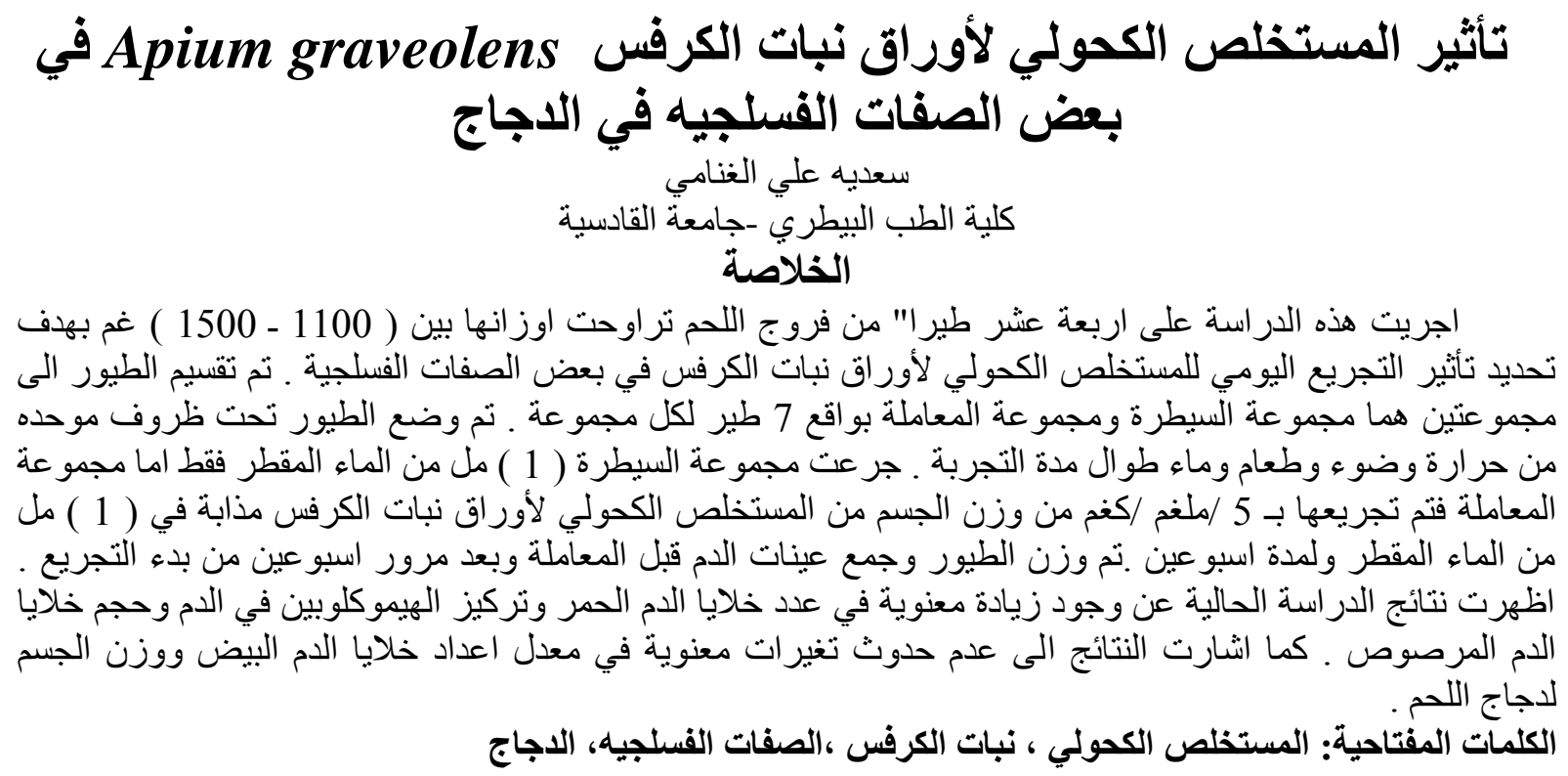

\section{Introduction}

Historically, all medicinal preparations were derived from plants, whether in the simple form of plant parts or in the more complex from of crude extracts, mixtures, etc. (1). Apium graveolens is a biennial herb that has been used consistently throughout history in medicinal preparations, food flavoring and preparation, and is known in the vernacular as A.graveolens (2). Apium graveolens is a flowering biennial from the family umbellifera. (3). A. graveolens has been used as an aphrodisiac, anthelmintic, antispasmodic, carminative, diuretic, emmenagogue, Laxative, sedative, stimulant, and toxic $(4,5)$. Extracts of $A$. graveolens have been investigated for their hepatoprotective, antinociceptive, anti inflammatory and antihyperlipidemic properties. The studies show that $A$. graveolens extract can exhibit a degree of protection against established hepatoxins, including carbon tetrachloride, acetaminophen (paracetamol), and thioacetamide $(6,7,8)$. The lipid lowering effects of Apium graveolens extract have 
been studied in rats $(9,10)$ and rabbits (11). A. graveolens and its flavonoid constituents have been investigated as neuroprotective agents against neurodegenerative pathologies that result from inflammatory etiologies. Extracts of $A$. graveolens leaves and roots have been shown by both in vitro and in vivo experiments to protect against oxidative stress and these antioxidant effects may be a result of the flavonoid content of $A$. graveolens (12). Luteolin and additional falvonoids have been shown to reduce the release of reactive oxygen species and to increase expression of enzyme that protect antioxidant properties $(10,13)$. In addition, the flavonoids apigenin and luteolin exhibit high biological activity and pronounced anti - inflammatory effects (14).

\section{Materials and methods}

1- preparation of alcoholic extract for Apium graveolens .It is extracted according to Harbone, (1975). (15).

2- Experimental animals. This experiment carried out in animal house in college of veterinary medicine in $\mathrm{AL}-$ Qadisiya university, fourteen local chickens were used $(55-65)$ days in age , $(1100-1500) \mathrm{gm}$ in weight, the chickens putted in cages and housed in same condition, include temperature, lighting, food, and water. The birds divided for two equal group. seven birds for each group:-

A-control group: administered $1 \mathrm{ml}$ of distilled water for two weeks.

B-treatment group: administered $1 \mathrm{ml}$ (contain $10 \mathrm{mg} / \mathrm{kg}$ ) B . W. of Apium graveolens extract for two weeks .

3- samples collection : - Blood samples were collected ( $2 \mathrm{ml} /$ bird ) from wing vein before and after treatment by using of syringe contain heparin as anticoagulant .

4- Blood parameters : -

A-Red blood cells count ( cell $/ \mathrm{mm}^{3}$ ). The red blood cells were counted ( cell $/ \mathrm{mm}^{3}$ ) by using of hemocytometer and diluting fluid and special pipette (16).

$\mathrm{B}-$ Hemoglobin concentration $(\mathrm{g} / \mathrm{dl})$ it is measured by cyanomet hemoglobin method by using Drabking's reagent (17).
C-Packed cell volume (\%) it is measured by microhematocrit and capillary tubes contain heparin, and put in microcenterifuge in $12000 \mathrm{Rpm}$ for five minutes and measured packed cell volume by service device (18, 19).

D-White blood cells count ( cell / $\mathrm{mm}^{\mathbf{3}}$ ) it is measured by hemocytometer and Thomas solution and special pipette ( 20 ).

E-Statistical analysis:- The obtained data were analyzed by complete Randomized Design (CRD) and least significant Differences (LCD) to compare parameters averages between control and treatment group $(\mathrm{p} \leq 0.05)(21)$.

\section{Results and discussion}

The results of the present study revealed that cavage chickens treated with 10 $\mathrm{mg} / \mathrm{kg}$. B. W. of Apium graveolens alcoholic extract shown significant increase $(\mathrm{p} \leq 0.05)$ in Erythrocytes count (table 1) and hemoglobin concentration (table2) and packed cell volume (table 3 ) in treated group compared with control group. This increase may be due to stimulation of Erythropoiesis by Erythropoetin which is released from the kidney (22). Some components of Apium graveolens cause increase the level of this hormone which then lead to increase Erythrocytes production and then increase hemoglobin concentration and packed cell volume (23) Also this increase may be due to involving of Apium graveolens of high quantity of Iron which consider essential element in Erythropoiesis (24) Also this increase may be return to antioxidants that found in Apium graveolens like 2 - methyl propanol, gomoselenine and actadecenamide which protect Erythrocyte membrane against free radicals action and lipid peroxidation and this may prevents Erythrocyte lyses ( 25 , 26). Therefore the increase of total erythrocytes number lead to increase in hemoglobin concentration and packed cell volume. Also the result of this study was revealed that there are non-significant differences $(p>0.05)$ in Leucocytes number between control and treated group (table 4) . which may be due to little dose $(10 \mathrm{mg} / \mathrm{kg})$ of extract, which don't cause immune 
response, also remaining of these cells within normal value may indicate that reserving of extract don't cause any stress to the birds while these cells increase due to stress infection (17) also there is increase in body weight of treated group when compared with control, but this increase is nonsignificant ( $p>0.05)$ (table 5). which may be due to role of Apium graveolens in increase proteins level and improvement of metabolism and energy. The Apium graveolens contain glycosides which have stimulatory effect for proteins anabolism and prevent their catabolism . $(27,28)$.

Table (1)Effect of alcoholic extract of Apium graveolens leaves on Erythrocytes count (million cell / $\mathbf{m m}^{3}$ ) for Broilers .

\begin{tabular}{|c|c|c|}
\hline group & pretreatment & post treatment \\
\hline \multirow{2}{*}{ control } & $\mathrm{aA}$ & $\mathrm{aA}$ \\
& $2.99 \pm 0.28$ & $3.32 \pm 0.28$ \\
\hline \multirow{2}{*}{ treatment } & $\mathrm{aA}$ & $\mathrm{bB}$ \\
& $2.47 \pm 0.25$ & $4.40 \pm 0.42$ \\
\hline
\end{tabular}

Numbers $=$ mean \pm standard error The different small letters means significant differences within group $(\mathrm{p} \leq 0.05)$ The different capital letters means significant differences between groups $(p \leq 0.05)$.

Table (2)Effect of alcoholic extract of Apium graveolens leaves on hemoglobin concentration mean ( $\mathrm{gm} / \mathrm{dl})$ for Broilers.

\begin{tabular}{|c|c|c|}
\hline group & pretreatment & post treatment \\
\hline \multirow{2}{*}{ control } & $\mathrm{aA}$ & $\mathrm{aA}$ \\
& $11.1 \pm 0.54$ & $11.6 \pm 0.54$ \\
\hline \multirow{2}{*}{ treatment } & $\mathrm{aA}$ & $\mathrm{bB}$ \\
& $11.4 \pm 0.89$ & $13.6 \pm 0.54$ \\
\hline
\end{tabular}

Numbers $=$ mean \pm standard error The different small letters means significant differences within group $(p \leq 0.05)$.The

\section{References}

1. Ayyanar M , and Ignacimuthu S. ( 2009 ) . Herbal medicines for wound healing among tribal people in southern India : Ethnobotanical and scientific evidences Inernational Journal of Applied Research in Natural products vol .2 ( 3 ) : $29-42$

2. Gruen wald , J . ed. (2000 ) . PDR for herbal medicines . $2^{\text {nd }}$ Edition . Montvale , New Jersey : medical Economics company $172-174$.

3. Rastogi SC, schouten A , De kruij FN, and weijbnd JW . ( 1995). contents of methy - lethyl ., propyl ., butyl - and benzyl paraben in cosmetic products . contact Dermatitis $28-30$.

4. Wuest, J . R . and Gossed, T . A . ( 2002 ) . containing Education for pharmacists : Natural different capital letters means significant differences between groups $(\mathrm{p} \leq 0.05)$.

Table (3)Effect of alcoholic extract of Apium graveolens leaves on pocked cell volume mean ( \% ) for Broilers.

\begin{tabular}{|c|c|c|}
\hline group & pretreatment & post treatment \\
\hline \multirow{2}{*}{ control } & $\mathrm{aA}$ & $\mathrm{aA}$ \\
& $33.20 \pm 0.96$ & $33.60 \pm 0.81$ \\
\hline \multirow{2}{*}{ treatment } & $\mathrm{aA}$ & $\mathrm{bB}$ \\
& $32 \pm 1.22$ & $44.80 \pm 1.21$ \\
\hline
\end{tabular}

Numbers $=$ mean \pm standard error The different small letters means significant differences within group $(\mathrm{p} \leq 0.05)$. The different capital letters means significant differences between groups $(\mathrm{p} \leq 0.05)$.

Table (4)Effect of alcoholic extract of Apium graveolens leaves on leukocytes count ( cell $/ \mathrm{mm}^{3}$ ) for Broilers.

\begin{tabular}{|c|c|c|}
\hline group & pretreatment & post treatment \\
\hline \multirow{2}{*}{ control } & $\mathrm{aA}$ & $\mathrm{aA}$ \\
& $2696 \pm 138$ & $2696 \pm 138$ \\
\hline \multirow{2}{*}{ treatment } & $\mathrm{aA}$ & $\mathrm{aA}$ \\
& $2528 \pm 129$ & $2560 \pm 183$ \\
\hline
\end{tabular}

Numbers $=$ mean \pm standard error The similar letters means non-significant differences $(\mathrm{P}>0.05)$

Table (5)Effect of alcoholic extract of Apium graveolens leaves on body weight mean ( gm ) for Broilers.

\begin{tabular}{|c|c|c|}
\hline group & pretreatment & post treatment \\
\hline \multirow{2}{*}{ control } & $\mathrm{aA}$ & $\mathrm{aA}$ \\
& $1350 \pm 70$ & $1350 \pm 70$ \\
\hline \multirow{2}{*}{ treatment } & $\mathrm{aA}$ & $\mathrm{aA}$ \\
& $1340 \pm 73$ & $1560 \pm 79$ \\
\hline
\end{tabular}

Numbers $=$ mean \pm standard error similar letters means nonsignificant differences $(\mathrm{p}>0.05)$.

products : cascara tocentaury :American Botanical . www. Herbal gram council .

5. Fazal SS \&single RK.( 2012).Review on the pharmacognostical and pharmacological characterization of Apium graveolens linn. Indo Global J. Pharmacutical Sci. 2 ( 1 ) : 36 - 42.

6. Singh A , and Handa SS . ( 1995 ) : Hepatoprotective activity of Apium graveolens and hygrophila auriculata against paracetaol. Mol \& thioacetamide intoxication in rats Ethanopharmacol,Dec ., $15 ; 4$, (3) : 119 - 126.

7. Ahmed B, Alam T, and Khan SA ., ( 2002). Hepatoprotective activity of two plants helonging to the Apiaceae mar $313-6$. 
8. Jakovjevic . V ., Raskovic , A .; Popovic, M . and sobo , J . (2002).effect of celery \& parsely juiceson pharmaco - dynamic activity of drugs involving cytochrom p450 in their metabolism. Eur. J.Drog metab pharmacokinet, 27 ( 3 ) : 153-156 .

9. Tsi D, Das NP, and Tan S . ( 1995 ). Effect of aqueous celery ( Apium graveoleus ) extract on lipid parameter of rats fed high fal diet, planimed $., 61$ ( 1$): 18-21$

10. Al - sa'aidi J . A . A , Alrhodan M . N . A ., and Asmael AK ., (2012). A ntioxidant activity of $n-$ butanol extract of celery( Apium graveolens ) seed in sereptozocin induced male rats .Research in pharmaceutical Biotechnology , 4 ( 2 ) : $24-29$.

11. Al Jabori A .,(2009) . A comparative study of the effect of insulin\& alcoholic extract of A. graveolens seed on the treatment of experimentally induced diabetes mellitus in mature mola rabbit. MSC thesis , college of vet . med ., Al Qadisiya univ ., Iraq .

12. popovic M ., kournovic B ., Trivic S ., Mimica Dukic N ., And Bursac M .( 2006 ) : Effect of celery ( Apium graveolens )extract on some bio chemical parameters of oxidants stress in mice treated eight carbon tetrachloride, phototherapy research $20(7): 531-537$.

13. Sharma V., ( 2007 ) . Modalation of interleukin - 1 beta mediated inflammatory response inhuman astrocytes by flaronids : implications in neuroprdetion Brain Res. Bull . 73 ( 13 ): 55 - 63 .

14. Benavente - Gorcia , O . ( 2008 ) . Updata on uses and properties of citrus falvonoid : new findings in anticancer ,cardiovascular, and anti inflammatory activity . J .Agric . food chem. ., 56 ( $15): 6185-6205$.

15. Harbone , J . B . Mabray, T . J .; and Mabray, H . ( 1975 ) .Physiology and function of flavonoid P . : 975 - 1042. The flovoids . Acad . press , New York, san francis co .

16. Sood , R. ( 1996 ) . Hematology for students and practitioners, $4^{\text {th }}$,ed . Jaypee brother medical publishers , ( p ) LTD . ; India 318 - 325 .
17. Coles , E . H. ( 1986$)$. veterinary clinical pathology $4^{\text {th }}$. ed . W.B. sounders Co . Philadelphia , Londan . PP : 15 , 20 , 53 - 56, 67 , 139 .

18. Schalm , O .W ; Jain ; N . C . ; and carrol , E . J . ( 1975 ). Veterinary hematology . Leo and febiger, ed , philadelphia .pp : $152-140$.

19. Green , J .H . ( 1976 ) . An introduction to human physiology $4^{\text {th }}$ ed. New York. Tokyo, pp : 5-6.

20. Dacie , J .V . and Lewis , S . M . ( 1984 ). practical hematology. $6^{\text {th }}$. ed ., Edinburgy , Churchill, pp : $40-55$.

21.S need Core, G.W. \& Cochran, W.G. (1973). Statistical Methods. Iowa State University Press, Ames, Iowa, USA.

22. Guyton , A . C . and Hall , J . E . ( 2006 ). Textbook of medical physiology . $9^{\text {th }}$ ed . Philadelphia . WB . saunders company . $980-981$

23. Falzari , L . and Menarty R . ( 2005 ). Development of a celery oil and extract industry . Rural industries Research and Development corporation ., $5: 133$.

24. Momin , R . A . and Nair , M . G ( 2002 ). Antioxidant cyclo- oxygenase and Topoismerase inhibitor, compound from Apium graveolens seeds . phytomedicine ., 9(4):312-318.

25. Cheng, M . C . ; Lin , I . Y . ; Tung , H . and Peng , R . ( 2008 ) .Hypolipidemic and antioxidant activity of mountain celery essential oil . J . Agric . food chem. ;56( 11 ) :3997 - 4003 .

26. Pendary , B . J . , Busia , K . and Bell , C . M . ( 2008 ) phytochmical evalution of selected antioxidant containing medicinal of plant for use in the preparation of a herbal ,A preliminary study . 2 ( 7$): 917-922$.

27. Glombitza , K . W . ; Mabran , G . H . ; M . Yhon, Y . W . ; Michel, K.G . and Motawi , K . ( 1994 ) . Hypoglycemic effect of Zizuphus spinachristi in rats - planta , med . $60,244-247$.

28. Baily , C . T . and Day , L . ( 1989 ). Traditional plant medicine as treatment for diabetes care , 12 : $553-564$. 